\title{
MEMBANGUN KARAKTER SEKOLAH BERMUTU MELALUI KOMUNIKASI YANG EFEKTIF
}

\author{
Ruslan \\ SD NEGERI GELOGOR \\ ruslan_haji@gmail.com
}

\begin{abstract}
Dalam banyak hasil penelitian dan kasus, sekolah bermutu seringkali diidentikkan dengan sekolah baik, sekolah efektif atau sekolah yang excellent dan bahkan disebut sebagai sekolah unggul. Menuju sekolah yang bermutu banyak hal yang harus dilakukan. Mulai dari mendasari sekolah dengan komunikasi yang efektif guna menyepakati dan membangun spirit (nilai) yang mendasari pembenahan suatu lembaga pendidikan agar menjadi bermutu. Spirit tersebut akan tercermin pada visi dan misi sekolah, struktur organisasi dan deskripsi tugas, system dan prosedur kerja, kebijakan dan aturan, tata tertib, fasilitas sekolah serta suasana dan hubungan termasuk pada sikap dan prilaku kepala sekolah, guru dan tenaga kependidikan lainnya/warga sekolah. Dengan dasar inilah pengembangan sekolah bermutu dapat dikembangkan. Dalam konteks ini komunikasi efektif berperan dalam memformat perumusan tujuan pengambangan dan penetapan kebijakan, sosialisasi dan implementasi, evaluasi dan follow up pengembangan lembaga pendidikan. Selanjutnya berdasarkan pelaksana dapat menyelenggarakan sekolah yang bermutu (efktif dan unggul) secara penuh/maksimal. Agar praktek ini lebih cepat terealisasi diharapkan agar sekolah menerapkan langkah ini dengan baik dan benar serta selalu melakukan inovasi dan mencari pendekatan baru dalam upaya membangun sekolah yang bermutu.
\end{abstract}

\section{Keywords: karakter sekolah bermutu dan komunikasi efektif}

\section{PENDAHULUAN}

Telah banyak dilakukan penelitian oleh pakar manajemen pendidikan mengenai sekolah yang bermutu. Dalam penelitian sekolah yang bermutu sering disebut sekolah yang efektif atau sekolah yang excellent atau sekolah yang unggul (Sergiovanni, 1987). Sebenarnya ada dua model pendekatan yang sangat berguna dalam menetapkan sekolah bermutu (Hoy \& Ferguson, 1985), yaitu model pendekatan pencapaian tujuan dan model pendekatan proses. Pada model pendekatan pencapaian tujuan, model ini berdasarkan pandangan tradisional organisasi dikatakan efektif apabila mencapai tujuan yang telah ditetapkan (Sergiovanni, 1987). Di sekolah biasanya dilihat tingkat pencapaiannya yang ditandai dengan prestasi lulusan sekolah. Dengan demikian model pendekatan tujuan ini, prestasi siswa merupakan peranan penting yang digunakan dalam menetapkan baik atau tidaknya sekolah.

Model pendekatan proses memandang organisasi sebagai sebuah system terbuka, Jurnal Ilmiah Mandala Education terdiri dari masukan transformasi dan keluaran (Hoy \& Miskel, 1982). Model ini dilihat bukan dari tingkat pencapaian tujuan melainkan konsistensi internal, efisiensi penggunaan sumber yang ada dan kesuksesan mekanisme kerjanya (Hoy\&Ferguson, 1985). Ada dua asumsi yang melandasinya, yaitu (1) organisasi merupakan sebuah sistem terbuka yang harus mampu memanfaatkan dan merefleksikan lingkungan sekitarnya dan (2) organisasi merupakan sistem yang dinamis dan besar, maka kebutuhannya kompleks, sehingga tidak mungkin didefinisikan hanya melalui sejumlah kecil tujuan organisasi.

Sekolah bermutu (efektif atau unggul) memiliki kriteria tertentu. Parameter dasarnya adalah (1) standar kerja yang tinggi dan jelas bagi siswa; (2) mendorong aktifitas, pemahaman multibudaya, kesetaran gender dan mengembangkan secara tepat pembelajaran menurut standar potensi yang dimiliki pelajar; (3) mengharapkan siswa mengambil peran tanggung jawab dalam belajar dan perilaku dirinya; (4) mempunyai instrumen evaluasi dan penilaian prestasi 
belajar; (5) menggunakan metode pembelajaran yang berakar pada penelitian pendidikan dan praktik profesional; (6) mengorganisir sekolah dan kelas guna mengkreasi lingkungan yang mendukung pembelajaan; (7) pembuatan keputusan secara demokratis dan akuntabilitas; (8) menciptakan rasa aman, sifat saling menghargai dan mengakomodasikan lingkungan secara efektif; (9) mempunyai harapan tinggi kepada staf; (10) melibatkan keluarga di dalam membantu siswa untuk mencapai sukses dan (11) bekerja sama dengan masyarakat dan pihak lain (Danim, 2006).

Hampir serupa yang dikemukakan Danim, Sammons (dalam Macbeath \& Mortimore, 2005) menganalisis tentang sekolah bermutu yang ditentukan 11 faktor penting, yaitu: kepemimpinan profesional, visi dan tujuan bersama, suatu lingkungan pembelajaran, konsentrasi pada belajar dan mengajar, harapan tinggi, dorongan positif, meminitor kemajuan, hak dan kewajiban murid, pengajaran yang mempunyai tujuan, suatu organisasi pembelajaran, dan kemitraan sekolah rumah. Sementara ahli lain menegaskan bahwa sekolah unggul bercirikan (1) memiliki budaya akademik yang kuat; (2) memiliki kurikulum yang selalu relevan dengan perkembangan ilmu pengetahuan dan teknologi; (3) memiliki komunitas sekolah yang selalu menciptakan cara atau teknik belajar untuk belajar yang inovatif; (4) berorientasi pada pengembangan hard and soft knowlegde secara seimbang; (5) proses belajar untuk mengembangkan potensi siswa secara holistik dan (6) mengembangkan proses pengembangan kemampuan dan kompetensi ber-komunikasi siswa secara global (Suyanto dalam Elfahmi, 2006).

Sedangkan hasil penelitian Austin menemukan bahwa sekolah yang sukses menunjukkan saling ketergantungan sehubungan denan praktek tertentu dalam organisasi sekolah. Dalam kaitan ini, karakteristik yang ditemukan dalam sekolah tersebut, adalah (1) kepemimpinan instruksional yang kuat; (2) pengembangan program, perencanaan pengajaran; harapan performansi yang tinggi; kepercayaan bahwa semua siswa dapat mempelajari keterampilan dasar; (5) iklim yang positif; (6) pengawasan terhadap fungsi sekolah, kurikulum dan program pengembangan staf; (7) dukungan staf yang kuat; (8) pemberian semangat serta (9) tanggung jawab dan partisipasi siswa (Moedjiarto, 2002).

Sekolah dapat disebut sebagai sekolah bermutu bila memiliki karakteristik keefektivan yang tinggi, yaitu: iklim sekolah yang positif, proses perencanaan sekolah yang melibatkan seluruh warga sekolah, harapan yang tinggi terhadap prestasi akademik, pemantauan yang efektif terhadap kemajuan siswa, dan keefektivan guru. Hal lain yang juga harus terpenuhi adalah kepemimpinan instruksional yang berorientasi pada prestasi akademik, pelibatan orang tua yang aktif dalam kegiatan sekolah, kesempatan, tanggung jawab dan partisipasi siswa yang tinggi di sekolah. Untuk mendukung pencapainnya, maka sekolah juga harus menerapkan ganjaran dan insentif di sekolah, yang didasarkan pada keberhasilan, tata tertib dan disiplin yang baik di sekolah dan pelaksanaan kurikulum yang jelas.

Pendidikan mencakup semua aktifitas, mulai konsep, visi, misi, institusi, kurikulum, metodologi, proses belajar mengajar, SDM kependidikan, lingkungan pendidikan dan lain sebagainya, yang disemangati dan bersumber pada ajaran dan nilai yang dibangun dalam proses semua aktiftas tersebut. Kelembagaan pendidikan yang bermutu tersebut adalah lembaga pendidikan atau sekolah yang merefleksikan konsep the good school, the effective school, the excellent school. Dengan dasar ini, Hasan (2005) menyampaikan bahwa ada empat persyaratan kelembagaan pendidikan bermutu, yaitu (1) SDM kependidikan yang professional; (2) manajemen yang efektif dan professional; (3) lingkungan pendidikan yang kondusif dan (4) mampu membangun kepercayaan kepada masyarakat.

Artinya bahwa SDM (sumberdaya manusia) kategori pendidik harus sesuai dengan standar yang telah ditetapkan berdasarkan seleksi yang memenuhi syarat 
kompetensi personal. Mereka juga harus memiliki kompetensi professional, kompetensi moral dan kompetensi sosial. Termasuk mampu berperan sebagai pengajar, pendidik dan sekaligus pemimpin di tengah peserta didiknya. Selain itu, tenaga kependidikan tersebut memiliki pengalaman dan ditunjang keunggulan dalam kemampuan intelektual, moral, keilmuan, ketaqwaan, disiplin dan tanggung jawab. Memiliki keluasan wawasan kependidikan, kemampuan pengelolaan, terampil, kreatif, memiliki keterbukaan profesional dalam memahami profesi, karakteristik dan masalah perkembangan peserta didik. Kemampuan terpenting yang mutlak harus dikuasai adalah kemampuan mengembangkan rencana studi dan karir peserta didik serta memiliki kemampuan meneliti dan mengembangkan kurikulum, menguasai agama dan ketaatan beribadah maupun amaliyahnya.

Manajemen pendidikan diharapkan
dapat berperan menjadi empowering organization. Dalam pemberdayaan organisasi, komponen harus didayagunakan sehingga bersinergi mencapai tujuan secara efektif dan efisien. Diantara komponen tersebut adalah kurikulum atau pembelajaran, siswa, pegawai, sarana prasarana, keuangan dan lingkungan masyarakat (De Roche, 1985). Dalam pelaksanaan keseluruhan proses manajemen tersebut diupayakan bertumpu pada spirit manajemen pendidikan bermutu sebagaimana temuan teoritik pada berbagai hasil penelitian yaitu berwawasan mutu, kemandirian, partisipasi dan keterbukaan. Setidaknya terdapat empat langkah proses manajemen pendidikan yang professional, yaitu: perencanaan, pengorganisasian, pengerahan (kepemimpinan) dan pengendalian (Bafadal, 2002). Dalam membentuk budaya mutu sekolah, lembaga pendidikan merupakan sebuah organisasi. Kultur lembaga pendidikan merupakan kultur organisasi dalam konteks satuan pendidikan. Dengan demikian kultur lembaga pendidikan dapat diartikan sebagai kualitas kehidupan sebuah lembaga pendidikan yang tumbuh dan berkembang berdasarkan spirit dan nilai tertentu yang dianutnya. Kultur lembaga pendidikan tersebut akan dapat dikembangkan dengan melalui tenaga kependidikan yang unggul.

Persyaratan yang ketiga yang harus terpenuhi untuk kelembagaan (sekolah) yang bermutu adalah lembaga pendidikan tersebut harus mampu menciptakan lingkungan pendidikan yang kondusif, yang memberikan suasana damai, bersih, tertib, aman, indah dan penuh kekeluargaan. Lingkungan yang memberikan kebebasan peserta didik untuk berekspresi, mengembangkan minat dan bakatnya, berinteraksi sosial dengan sehat dan saling menghormati, dalam atmosfir yang mencitrakan suasana religius, etis dan humanis.

Membangun kepercayaan kepada masyarakat merupakan persyaratan terakhir. Lembaga pendidikan harus mampu membangun kepercayaan masyarakat atas programnya sehingga memperoleh dukungan dan partisipasi dalam bentuk pemikiran dan pembiayaan. Sekolah diharapkan mampu melakukan hubungan simbiosis mutualisme dengan masyarakat di lingkungan sekolah. Kondisi ini akan membuat sekolah mendapat dukungan penuh dari masyarakat.

\section{PEMBAHASAN}

\section{Pengembangan Budaya Mutu di Sekolah Menuju Sekolah Unggul}

Pengembangan budaya mutu yang dilakukan dalam rangka mencapai keefektifan pendidikan di sekolah tentu dijiwai oleh spirit dan nilai hasil identifikasi. Pengembangan budaya mutu tersebut harus melalui tim khusus dan melibatkan semua warga sekolah, kemudian ditetapkan dengan kebijakan sekolah. Kebijakan yang telah diambil dan disepakati tersebut, disosialisasikan kepada semua warga sekolah baik melalui papan pengumuman, surat, edaran atau dilakukan komunikasi secara terbuka untuk dan agar dimengerti dan diterima sebagai aturan sekolah. Disamping itu juga dilakukan sosialisasi kepada wali murid. Setelah itu diimplementasi atau dilaksanakan bersamasama. Selanjutnya dilakukan evaluasi bersama melalui rapat rutin sekolah dan pertemuan dengan wali siswa, yang didalamnya termasuk menerima masukan 
yang berarti dalam rangka perbaikan sebagai tindak lanjut dalam keefektifan pendidikan di sekolah.

Pengembangan budaya mutu yang telah dilakukan di Sekolah Dasar Negeri Gelogor terdiri dari tiga tahap utama. Tahap pertama, merumuskan tujuan pengembangan yang dijiwai spirit, nilai dan penetapan kebijakan. Tahap ini terdiri dari beberapa kegiatan pengembangan seperti (1) mencapai keefektifan pendidikan di sekolah; (2) membentuk tim khusus; (3) melibatkan semua warga sekolah; (4) menetapkan kebijakan yang bersifat mikro/operasional dan (5) penetapan kebijakan pengembangan budaya mutu berdasarkan kesepakatan bersama. Tahap kedua merupakan tahap sosialisasi dan implementasi, diberikan kepada semua warga sekolah, wali murid melalui berbagai media seperti pengumuman, surat, edaran, komunikasi terbuka dan dilaksanakan secara bersama dengan baik. Sedangkan tahap ketiga meliputi evaluasi dan follow up, yang dilakukan secara bersama melalui rapat rutin, pertemuan dengan wali murid dan melakukan perbaikan sebagai tindak lanjut kegiatan.

Pengembangan budaya mutu tersebut di atas merupakan pengembangan sistematik dimulai dari perancangan perumusan tujuan termasuk identifikasi spirit dan nilai yang dijadikan landasan, penetapan kebijakan, sosialisasi dan implementasi sampai evaluasi terhadap implementasi serta dilakukan perbaikan sebagai follow up-nya. Seperti yang telah dilakukan Torrington \& Weightman (Preedy, 1993) ketika melakukan pengembangan budaya mutu sekolah melalui tiga tataran, yaitu (1) pengembangan tataran spirit dan nilai; (2) pengembangan tataran teknis; dan (3) pengembangan tataran sosial.

Pada tataran pertama, dengan cara mengidentifikasi berbagai spirit dan nilai kualitas kehidupan sekolah yang dianut sekolah. Pada tataran kedua, dengan cara mengembangan berbagai management work procedures, management toolkit dan management work habits berbasis sekolah yang betul-betul merefleksikan spirit dan nilai yang akan dibudayakan di sekolah. Sedangkan pada tataran ketiga, pengembangan tataran sosial dalam konteks pengembangan kultur sekolah adalah proses implementasi dan institusionalisasi sehingga menjadi sebagai suatu work habits di sekolah dan di luar sekolah.

Kondisi ini memberi pemahaman bahwa untuk membngun sekolah bermutu haruslah melalui beberapa tahapan sistematis. Tidak dapat dilakukan dengan serta merta tanpa perencanaan sebelumnya. Tahapan tersebut setidaknya meliputi tiga hal utama yaitu spirit pengembangan, pelaksanaan teknisnya dan pengembangan lingkungan sosial sehingga terbina suasana yang kondusif dan lembaga pendidikan pun akan mendapat dukungan penuh dari masyarakat.

\section{Komunikasi Efektif dan Nilai sebagai Sumberdaya Mutu Sekolah Unggul}

Satu hal yang sering membuat banyak orang berkonflik adalah kurangnya communication skills. Komunikasi sering dianggap remeh, padahal kesalahan dalam komunikasi dapat menimbulkan konflik yang mengganggu hubungan. Secara sederhana konsep komunikasi adalah proses penyampaian message dari komunikator kepada komunikan. Proses ini dapat menghasilkan feedback dari komunikan sehingga komunikasi dapat berlangsung secara two way antara komunikator dan komunikan. Setiap individu dapat berkomunikasi dengan gaya dan caranya masing-masing, tetapi tidak semua individu mampu berkomunikasi secara efektif. Komunikasi yang efektif dapat diartikan sebagai komunikasi yang dapat menghasilkan perubahan sikap pada orang lain. Attitude change biasanya terlihat ketika komunikasi berlangsung maupun pascakomunikasi.

Komunikasi yang efektif memiliki goals untuk memudahkan orang lain dalam memahami isi atau pesan yang disampaikan komunikator. Tujuannya adalah agar informasi yang disampaikan menghasilkan feedback dari komunikan. Karena faktor itulah, maka proses komunikasi yang efektif harus dilakukan menggunakan bahasa yang jelas dan tidak ambigu. Demikian juga dalam sekolah yang mengembangkan sekolah unggul wajib memperbaiki kualitas 
komunikasi dalam organisasi mereka. Semua saluran komunikasi organisasi arus terkelola dengan baik. Komunikasi organisasi yang perlu diperbaiki dapat berbentuk komunikasi vertikal, horizontal dan diagonal.

Komunikasi akan mengawali kerjasama tim dalam organisasi. Komunikasi yang efektif dalam membangun sekolah bermutu mutlak diperlukan mengingat semua yang dilakukan harus melalui kesepakatan dalam musyawarah. Termasuk dalam hal ini melibatkan unsur stakeholder pendidikan di wilayah lembaga pendidikan tersebut berada. Dalam situassi seperti ini maka semua lini fungsi komunikasi yang efektif dapat diwujudkan secara maksimal. Fungsi tersebut meliputi fungsi informasi, persuasi, regulatif dan integratif (Hasibuan, 2003).

Komunikasi yang dibangun di SDN Gelogor dalam upaya mewujudkan sekolah bermutu adalah komunikasi efektif yang melibatkan semua komponen baik secara vertikal, horizontal maupun diagonal. Dengan pola budaya komunikasi sehat dalam organisasi ini diharapkan perwujudan sekolah bermutu akan lebih cepat tercapai. Efektivitas komunikasi akan sangat menentukan kesuksesan manajemen sekolah dalam membangun sekolah bermutu baik dalam jangka pendek maupun jangka panjang. Hal ini juga akan mendukung lingkungan kerja di sekolah yang kondusif dalam suatu sistem nilai guna meningkatkan semangat dan kinerja serta motivasi kerja guru dan elemen pendidikan lainnya di sekolah.

Spirit dan nilai budaya merupakan kualitas kehidupan sebuah sekolah. Sebagai suatu organisasi, sekolah juga menganut budaya organisasi yang terdiri dari keseluruhan norma, nilai, keyakinan dan asumsi (Greemers dan Reynold, 1993). Nilai ini sejalan dengan yang dianut sekolah, yaitu disiplin, tanggung jawab, kebersamaan, keterbukaan, kejujuran, semangat hidup, sosial dan menghargai orang lain, serta persatuan dan kesatuan (Preedy, 1993). Nilai yang dijadikan sebagai sumber dalam membangun budaya mutu di SD Negeri Gelogor antara lain nilai perjuangan, ibadah, amanah, kebersamaan, disiplin, profesionalisme dan menjaga eksistensi sekolah. Spirit dan nilai tersebut, dijadikan landasan dan sumber oleh sekolah ini yang tercermin dalam setiap kegiatan, dalam mengambil keputusan, sikap dan perilaku warga sekolah, pola manajemen yang dilakukan dan lain sebagainya. Spirit dan nilai budaya mutu mewarnai dan nampak dalam penyelenggaraan pendidikan di sekolah.

Artinya antara komunikasi yang efektif dan spirit tidak dapat dipisahkan dalam mewujudkan sekolah yang bermutu. Dua hal tersebut merupakan elemen mendasar sekaligus sebagai sumber daya mutu di lembaga pendidikan. Sekolah akan dapat dengan cepat mencapai tujuannya, jika antarpelaku di sekolah tersebut dapat menentukan tindakan dan mengambil keputusan melalui komunikasi efektif yang dilakukan antarpelaksana di sekolah termasuk juga dengan pihak eksternal (wali murid dan komite sekolah, termasuk stakeholder).

Wujud Budaya Mutu Sekolah dasar yang Unggul

Sebenarnya budaya organisasi tersebut muncul dalam dua dimensi, yaitu dimensi intangible dan tangible, sebagaimana yang dikemukakan Calldwell dan Spinks (1993) bahwa dimensi intangible meliputi spirit/nilai, keyakinan dan ideologi. Sementara dimensi tangible meliputi kalimat, baik tertulis maupun lisan yang digunakan, perilaku yang ditampilkan, bangunan, fasilitas, serta benda yang digunakan di sekolah. Perwujudannya dapat diperhatikan pada visi dan misi sekolah, struktur organisasi dan deskripsi tugas, system dan prosedur kerja, kebijakan dan aturan di sekolah, taat tertib sekolah, fasilitas sekolah, suasana dan hubungan formal maupun informal serta sikap dan perilaku kepala sekolah, guru dan tenaga Kependidikan Lainnya

Visi yang diusung di SD Negeri Gelogor adalah Unggul dalam prestasi, maju dalam kreasi dan mantap dalam IMTAQ yang kemudian di-breakdown kedalam misi (1) melaksanakan pembelajaran dan bimbingan secara kreatif, efektif dan bermutu; (2) menumbuhkan motivasi belajar yang aktif dan meraih prestasi; (3) menciptakan proses 
belajar mengajar yang aman serta kondusif dalam mengembangkan profesi;

menciptakan lingkungan yang sehat, bersih dan berwibawa; (5) memupuk rasa persatuan dan kesatuan, penghayatan serta pengamalan ahlaqul qarimah yang berlandaskan iman dan taqwa.

Pada visi dan misi tersebut tercermin budaya mutu yang nampak pada (1) kegiatan dan praktek pembelajaran yang dilakukan melalui, pembiasaan, kegiatan ilimiah, pembiasaan bersikap dengan guru, orang tua dan teman; (2) program kunjungan ke tempat bersejarah, musium, instansi pemerintah (wali kota, DPRD) dan beberapa kegaitan pembelajaran yang dikemas dengan metode project based learning (PBL) dan (3) penggunaan multi strategi pembelajaran seperti pembelajaran outdoor, pembelajaran melalui pengamatan, praktek, diskusi kelompok, CTL (contextual teaching and learning), $\mathrm{PBL}$, bilingual, pembelajaran berbasis ITC dan sejumlah kegiatan ekstrakurikuler.

Visi dan misi sekolah dijadikan pedoman guru dalam melaksanakan pembelajaran di kelas maupun kegiatan sekolah lainnya, termasuk orang tua siswa dalam mengarahkan dan bimbingan di rumah. Karena visi dan misi sekolah dianggap sebagai salah satu budaya mutu sekolah yang merupakan perpaduan nilai, keyakinan, asumsi, pemahaman dan harapan yang diyakini warga sekolah atau kelompok serta dijadikan sebagai pedoman bagi perilaku dan pemecahan masalah yang dihadapi (Hodge \& Anthony, 1988).

Dilihat dari segi keefektifan visi dan misi sekolah yang dapat mengarahkan semua warga sekolah dalam melaksanakan tugas dan fungsinya di sekolah sehingga menumbuhkan interaksi positif, telah menunjukkan pertumbuhan lembaga pendidikan sebagai suatu organisasi yang efektif. Beberapa ciri budaya organisasi yang efektif antara lain (1) adanya dukungan bagi interaksi social; (2) dukungan bagi kegiatan intelektual atau belajar dan (3) komitmen yang kuat terhadap visi dan misi organisasi (DeRoche, 1985).
Dalam konteks struktur organisasi dan deskripsi tugas, penyelenggara pendidikan dikelompokkan menjadi dua organ. Pertama pengelola yang bertugas dan berwenang makro. Bersifat makro ditetapkan oleh organ pengelola sebagai pedoman umum pelaksanaan operasional di sekolah, meliputi sistem dan prosedur rekrutmen tenaga baru, pembinaan kepangkatan, ketentuan cuti, peraturan disiplin kepegawaian, sistem seleksi penerimaan siswa baru, penetapan kurikulum dan lain sebagainya.

Kedua sekolah sebagai organ pelaksana pendidikan yang mempunyai tugas dan wewenang bersifat mikro/operasional. Semua kebijakan operasional harus mengacu pada kebijakan makro yang telah ditetapkan oleh organ pengelola dan merupakan garis instruktif. Penyelenggara operasional dipimpin seorang kepala sekolah yang dibantu guru dan tenaga tata usaha. Pembagian tugas diantara kepala sekolah, guru dan tenaga tata usaha harus selalu dievaluasi keefektifannya, sehingga pola manajemen yang dilakukan secara dinamis disesuaikan perkembangan dan kebutuhan riil di sekolah. Garis instruktif kepala sekolah langsung kepada unsur akademik, administratif dan penunjang. Sementara garis koordinatif dengan BP3/komite sekolah/forum orang tua siswa. Sedang garis koordinatif diantara ketiga unsur tersebut dalam rangka keefektifan penyelenggaraan sekolah.

Di SD Negeri Gelogor, peran ini diterjemahkan dalam rangka mempertegas, memperjelas dan mengkonkritkan kebijakan makro. Bagian ini meliputi (1) upaya meningkatkan profesional kerja dengan sistem pengumpulan media yang dibuat sendiri oleh guru; (2) meningkatkan keaktifan guru agar melakukan penyiapan rancangan pembelajaran dengan baik (kreatif dan inovatif); (3) melakukan pembinaan dan pengiriman tenaga pendidik maupun kependidikan untuk mengikuti kegiatan peningkatan kapasitas; (4) mengikutkan guru/pegawai dalam kegiatan pelatihan/diklat/ lokakarya baik yang diselenggarakan oleh organ pengelola sekolah maupun pihak luar dan lain sebagainya dan (5) menerapkan 
sistem reward dan punishment bagi siswa dan guru

Budaya mutu tersebut di atas, selaras dengan rumusan Depdiknas (2000) tentang elemen budaya mutu sekolah khususnya pada elemen yang ketiga dan keempat, yaitu hasil diikuti rewards atau punishment dan kolaborasi, sinergi, bukan persaingan se-bagai dasar kerjasama. Disamping itu, berarti sekolah ini telah memiliki budaya akademik yang kuat dan komunitas sekolah selalu menciptakan cara-cara yang inovatif, yang merupakan diantaranya ciri-ciri yang dimiliki oleh sekolah unggul (Suyanto dalam Elfahmi, 2006).

Kebijakan dan aturan sekolah bermutu adalah strategi dalam mencapai tujuan sekolah yaitu dalam rangka peningkatan mutu dan keefektifan sekolah. Pembuatan kebijakan dan aturan sekolah di SD Negeri Gelogor melibatkan semua unsur sekolah yang dapat dikategorikan menjadi (1) pembuatan kebijakan dan aturan sekolah oleh pimpinan sekolah untuk hal yang sudah jelas dan memang menjadi kewenangan seorang kepala sekolah dengan terlebih dahulu meminta pendapat warga sekolah; (2) kebijakan yang bersifat krusial digodok melalui tim khusus yang diberi wewenang oleh sekolah kemudian dilakukan sosialisasi sebelum ditetapkan, misalnya masalah kedisiplinan, PBM, pelayanan kepada siswa dan lain sebagainya dan (3) kebijakan dan aturan sekolah yang bersifat teknis, misalnya peringatan hari besar nasional dan Islam, teknis layanan makan siang, kunjungan wisata dan lain sebagainya dapat muncul dari warga sekolah, sekolah mengkaji, menyetujui dan menetapkannya.

Disamping hal tersebut di atas, kebijakan mengenai kebiasaan dalam seharihari di bahas melalui kesepakatan semua warga sekolah. Hal ini dilakukan dibuat dalam rangka peningkatan mutu atau keefektifan sekolah, sebab dengan pelibatan dan partisipasi semua unsur sekolah (warga sekolah) akan tumbuh rasa memiliki dan menjadi milik bersama.

Budaya mutu sekolah yang nampak dalam pengambilan kebijakan sekolah di SD Negeri Gelogor adalah (1) mengarah pada Jurnal Ilmiah Mandala Education peningkatan mutu dan keefektifan sekolah; (2) melibatkan warga sekolah sehingga menumbuhkan rasa memiliki yang tinggi karena terakomodirnya masukan dan menjadi harapan semua staf dan (3) keputusan melalui kesepakatan dan demokratis. Ketiga wujud budaya mutu sekolah tersebut, kalau dikaji lebih mendalam merupakan kriteria yang digunakan sebagai pedoman untuk melihat tingkat keefektifan sekolah. Sekolah dikatakan bermutu atau tidak dapat diperhatikan melalui tiga kriteria, yaitu (1) pembuatan keputusan secara demokratis dan akuntabilitas; (2) menciptakan rasa aman, sifat saling menghormati dan (3) mengakomodasikan lingkungan secara efektif serta mempunyai harapan yang tinggi kepada semua staf (Danim, 2006).

Tata tertib sekolah terdiri dari (1) tata tertib untuk guru, pegawai dan warga sekolah dan (2) tata tertib khusus untuk siswa, yang mengatur akan keteraturan sekolah. Tata tertib sekolah berisi kewajiban yang harus dilaksanakan, larangan yang harus dihindari dan sanksi yang akan diberikan bagi yang melanggar kewajiban dan melakukan larangan sekolah. Tata tertib sekolah yang diterapkan di SD Negeri Gelogor dirasakan sudah baik dan mapan, karena dirasakan tidak memberatkan, proses pembuatan melalui dibentuknya tim khusus atau melibatkan warga sekolah yang tidak hanya pimpinan saja, tata tertib diterapkan tidak kaku dan bersifat reward. Disamping itu tata tertib yang dibuat tidak hanya mengatur ketentuan umum tetapi juga ada tata tertib yang mengatur ketentuan khusus.

Fasilitas yang dimiliki sekolah bermutu harus lengkap dan memadahi untuk menunjang proses pembelajaran yang baik termasuk pemberian pengalaman belajar bagi siswa. Sarana prasarana dan fasilitas sekolah yang dimiliki SD Negeri Gelogor antara lain gedung yang representatif, ruang kelas yang luas dan representatif, perpustakaan sekolah, tempat ibadah sebagai pusat pengembangan dan pusat kegiatan ibadah siswa, halaman dan lapangan olah raga dan lain sebagainya. Upaya lain yang dilakukan dalam optimalisasi 
pemanfaatan fasilitas pembelajaran adalah menerapkan sistem sekolah aman.

Dengan demikian budaya mutu yang nampak pada pemberdayaan fasilitas sekolah adalah adanya usaha optimalisasi, usaha perawatan dan pemanfaatan keefektifan dan efisiensi, adanya mekanisme pemakaian yang baik, adanya jaminan keamanan dan adanya pemantauan dan evaluasi oleh pimpinan sekolah. Dengan budaya mutu tersebut keefektifan penyelenggaraan pendidikan di sekolah, misalnya siswa lebih nyaman belajar di sekolah, suasana belajar yang menyenangkan, memudahkan belajar dan mengerjakan tugas bagi siswa. Keberadaan beberapa aspek tersebut menjadi indikator bahwa SD Negeri Gelogor sudah dapat dikatakan sebagai bermutu (Lezotte, 1983). Dikatakan sebagai sekolah yang unggul itu karena memiliki karakteristik berikut lingkungan sekolah yang aman dan tertib, iklim serta harapan yang tinggi, kesempatan untuk belajar dan mengerjakan tugas bagi siswa, dan beberapa unsur penunjang lainnya.

Suasana dan hubungan formal dan informal dibangun dalam upaya memperlancar dan memperkokoh komitmen warga sekolah. Sekolah sangat memperhatikan hubungan tersebut dengan wali siswa. Suasana kondusif yang dibangun di SD Negeri Gelogor melalui (1) komunikasi dan koordinasi pimpinan dengan warga sekolah yang kontinyu; (2) pemberian reward bagi yang berprestasi; (3) saling menghormati dan akrab; (4) membangun suasana maju, kreatif, inovatif, berbuat yang terbaik, tuntutan kerja keras, koordinatif, struktur kepegawaian yang jelas, hubungan antarindividu dan antara bawahan-pimpinan baik, serta perhatian secara individu siswa oleh guru dan (5) punishment bagi warga sekolah yang melakukan pelanggaran.

Wujud budaya mutu tersebut, senada dengan apa yang dikatakan oleh Peter dan Waterman (Hanson, 1996) tentang nilai budaya yang konsisten dilaksanakan sekolah yang bermutu. Sebagiannya termasuk dalam indikator rumusan Depdiknas (2000) tentang elemen budaya mutu sekolah. Nilai budaya yang secara konsisten dilaksanakan di sekolah Jurnal Ilmiah Mandala Education yang baik adalah mengutamakan mutu dan pelayanan, berupaya menjadi yang terbaik, memberikan perhatian penuh pada hal yang nampak kecil, tidak membuat jarak dengan klien, melakukan sesuatu sebaik mungkin, bekerja melalui orang (bukan sekedar bekerjasama atau memerintah), memacu inovasi dan toleransi terhadap usaha yang berhasil.

Sikap dan perilaku kepala sekolah, guru dan tenaga kependidikan di SD Negeri Gelogor mengacu pada tiga pilar yaitu (1) tuntunan agama dan norma umum. Acuan ini tercermin pada sikap adil, bertegur sapa, penyambutan siswa di pintu gerbang sekolah oleh guru, bersalaman, memberi salam, berdo'a sebelum dan selesai beraktifitas di sekolah, saling menghormati; (2) memberikan motivasi berprestasi, selalu belajar dari pengalaman, selalu melakukan evaluasi dan selalu memperbaiki untuk mencapai yang terbaik dan (3) memberikan keteladanan dan jiwa sosial, yaitu sopan santun, ramah, senyum, memberikan layanan yang terbaik, sabar, bersodaqoh dan lainnya.

Indikator budaya mutu yang tampak pada sikap tersebut selaras dengan yang dikemukakan Hasan (2005) tentang syarat kelembagaan pendidikan Islam yang efektif yaitu membentuk lingkungan pendidikan yang kondusif yang mampu menciptakan iklim dan kultur sekolah yang Islami (school climate and school culture). Lembaga yang memberikan suasana damai, bersih, tertib, aman, indah dan penuh kekeluargaan, lingkungan yang memberikan kebebasan peserta didik untuk berekspresi, mengembangkan minat dan bakatnya, berinteraksi dengan sehat dan saling menghormati, dalam atmosfir religius, etis dan humanis.

Penyelenggaraan pendidikan sekolah unggul tersebut di SD Negeri Gelogor dapat berjalan dengan baik, dikarenakan (1) adanya job description yang jelas; (2) adanya garis koordinasi dan garis instruksi yang jelas dan fungsional dan (3) adanya pola manajemen yang dilakukan secara dinamis sesuai perkembangan dan kebutuhan riil di sekolah. Penyelenggaraan yang didasari ketiga hal 
tersebut, pelaksanakan tugas pendidikan dapat dilaksanakan dengan efektif dan efisien.

\section{PENUTUP}

Tahap membangun karakter sekolah bermutu dengan mengembangkan komunikasi yang baik dan efektif secara umum meliputi (1) tahap perumusan tujuan pengembangan dijiwai spirit dan nilai yang dilanjutkan dengan penetapan kebijakan; (2) sosialisasi dan implementasi dan (3) tahap evaluasi dan follow up. Tahapan ini akan tercermin pada visi dan misi sekolah, struktur organisasi dan deskripsi tugas sekolah, sistem dan prosedur kerja sekolah, kebijakan dan aturan sekolah, tata tertib sekolah, penampilan fisik (fasilitas) sekolah, suasana dan hubungan formal dan informal serta budaya mutu pada sekolah unggul. Karena itu warga sekolah dan stakeholder termasuk pengawas dan pengelola pendidikan perlu dibekali pemahaman konsep tentang budaya organisasi, budaya mutu sekolah dan pengembangannya, serta konsep sekolah bermutu. Dengan pemahaman konsep yang baik, sekolah dapat mengembangkan budaya mutu dalam rangka pengembangan sekolah bermutu secara sistematis.

\section{REFERENSI}

Bafadal, I., 2002. Akselerasi Peningkatan Mutu Pendidikan Sekolah Dasar. Artikel diterbitkan di Jurnal FIP Universitas Negeri Malang.

Caldweel. B.J. \& J.M. Spinks., 1993. Leading the Self Managing School. London, Washington: The Falmer Press.

Danim, S., 2006. Visi Baru Manajemen Sekolah: dari Unit Birokrasi ke Lembaga Akademik. Jakarta: PT Bumi Aksara.

Departemen Pendidikan Nasional., 2000. Manajemen Peningkatan Mutu Berbasis Sekolah. Buku 1. Jakarta: Departemen Pendidikan Nasional, Direktorat Jenderal Pendidikan Dasar dan Menengah, Direktorat Pendidikan menengah Umum.

DeRoche, F.E., 1985. How School Administrators Solve Problem. Engelwood Cliffs. New Jersey: Prentice Hall, Inc.

Elfahmi, H.S., 2006. Sekolah Unggul: Menciptakan Sekolah sebagai Sumber Solusi dan Rumah yang Menyenangkan

Jurnal Ilmiah Mandala Education bagi Setiap Penghuninya. Makalah disajikan dalam National Congress \& Business Forum 2006 diselenggarakan Magistra Utama, Surabaya, 4 Maret 2006.

Greemers, B.P.M., \& Reynold, D. (ed)., 1993. School Effectiveness and School Improvement. An. International Journal of Research, Pollicy and Practice. Lisse: Sweets \& Zietlinger.

Hanson, E.M., 1996. Educational Administration and Organizational Behavior. Boston: Allyn and Bacon.

Hasan, M. Tholchah., 2005. Pendidikan Islam Sebagai Upaya Sadar Penyelematan dan Pengembangan Fitrah Manusia: Pidato ilmiah pada Penganugerahan Gelar Doktor Kehormatan (Doctor Honoris Causa) Dalam Bidang Pendidikan Islam pada 30 April 2005 di Universitas Islam Negeri Syarif Hidayatullah Jakarta. Jakarta: Universitas Islam Negeri Syarif Hidayatullah.

Hasibuan, Malayu S.P., 2003. Manajemen Sumber Daya Manusia, Edisi Revisi. Jakarta: Bumi Aksara.

Hodge, B.J., \& W.P. Anthony., 1988. Organizational Theory (3 rd. ed.). Boston, Massa-Chusetts: Allyn and Bacon, Inc.

Hoy, W.K \& Ferguson,J., 1985. A Theoretical Framework and Exploration of Organizational Effevtiveness in Schools. Journal of Educational Administration Quarterly, Volume 21 halaman 117-134.

Hoy,W.K \& Miskel, C.G., 1982. Educational Administration: Theory, Research and Practice $\left(2^{\text {nd }} e d\right)$. New York: Random House.

MacBeath, Jhon \& Peter Mortimore., 2005. Improving School Effectiveness: Memperbaiki Efektivitas Sekolah. Jakarta: Grasindo.

Moedjiarto., 2002. Karakteristik Sekolah Unggul, Cet. Ke-2. Surabaya: Duta Graha Pustaka.

Sergiovanni, Thomas J., 1987. The Principalship: A Reflective Practice Perspective. Newton, Mass: Allyn and Bacon. 